Rajasinghe, D., Aluthgama-Baduge, C. and Mulholland, G. (2021), "Researching entrepreneurship: an approach to develop subjective understanding", International Journal of Entrepreneurial Behavior \& Research, doi: https://doi.org/10.1108/IJEBR-10-2019-0601

\title{
Researching Entrepreneurship: An Approach to develop Subjective Understanding
}

\section{Duminda Rajasinghe}

Faculty of Business and Law, University of Northampton, Northampton, UK

\section{Chinthaka Aluthgama-Baduge}

University of Derby, Derby, UK

Gary Mulholland

AFG College with University of Aberdeen, Doha, Qatar

\section{Abstract}

\section{Purpose}

Entrepreneurship is a complex social activity. Hence, knowledge production in the field requires inclusivity and diversity within research approaches and perspectives to appreciate the richness of the phenomenon. However, the dominance of positivist research in the field is visible and the current qualitative research is also predominantly restricted to popular templates. This seems to have limited our understanding of entrepreneurship. This paper critically discusses the appropriateness of Interpretative Phenomenological Analysis (IPA) as an innovative qualitative research methodology that facilitates a fuller appreciation of the richness and diversity of entrepreneurship.

\section{Design/methodology/approach}

This conceptual paper critically evaluates IPA's relevance for the stated purpose by reviewing both entrepreneurship and IPA literature. It discusses how IPA's philosophical underpinnings facilitate scholars to appreciate the wholeness of the phenomenon and provides literature informed data analysis guidance thereby addressing some of the weaknesses of the qualitative research within the field. 


\section{Findings}

Critical evaluation of the literature suggests that IPA is an appropriate research methodology for entrepreneurship. It has the potential to address some interesting and timely questions to elaborate, deepen and qualify existing theory or to study relatively unexplored areas within the field. The laid-out guidance helps scholars to develop informed rationale for their research decisions and to ensure quality and rigour in qualitative research.

\section{Originality/value}

This paper promotes the analysis of how people make sense of their experience as a valid way of knowing. IPA has a unique identity as it incorporates phenomenology, hermeneutics and idiography as a way to explore first-hand human experience to uncover qualitative understanding of entrepreneurship. The clear guidance and justifications in the paper promote scholarly confidence and address some preconceptions related to rigour, quality and validity of qualitative studies. Incorporating IPA into entrepreneurship, the paper also contributes to the demand for diversity, inclusivity and pluralism in qualitative research perspectives and approaches.

\section{Key Words: Entrepreneurship, IPA, Qualitative Research \\ Paper type: Conceptual paper}




\section{Introduction}

Entrepreneurship is practised in a number of different ways (Stam, 2016) and is part of the lived world where people impart diverse meanings to their actions. It takes its shape from what and how individuals encounter the elements within the context in which they operate (Gaddefors and Anderson, 2017). Thus, we position entrepreneurship as a contextually situated (Stam, 2016; Brannback and Carsrud, 2016) social activity (Pittaway, 2000; Anderson, 2016; Rajasinghe and Mansour, 2019) grounded in entrepreneurs' experience (Aggestam and Keenan, 2002; Stam, 2016).

Therefore, it is vital that entrepreneurship research focuses more on developing contextually relevant knowledge (see Gartner and Birley, 2002; Davidsson, 2016; Anderson and Starnawska, 2008; Mole and Mole, 2010; Chell, 2013; Welter et al., 2016; Fuller-Love and Akiode, 2020). Such knowledge "production requires inclusivity, diversity, and pluralism in research perspectives and approaches" (Leitch et al., 2010, p. 79) to facilitate a fuller appreciation of the richness of entrepreneurship (Raco and Tanod, 2014; Anderson, 2015) rather than restricting the phenomenon to a few different variables. This open approach helps to acknowledge factors that may not be obvious or not known, by answering questions such as how entrepreneurs make sense of their experience of failure or business success, or how their identity changes during transitions (see section 5).

This paper aims to inspire such research by establishing IPA as a relevant research methodology to qualitatively address some important questions whilst contributing to the enhancement of methodological plurality within the field (see Van Burg et al., 2020). IPA is a health psychological research methodology which focuses on firsthand human experience and how individuals make sense of their experience (Larkin et al., 2011; Wagstaff and Williams, 2014). It helps scholars to explore entrepreneurship from a practitioner perspective by adopting a bottom-up approach which facilitates the fuller appreciation of what actually happens in this area of research (Raco and Tannod, 2014; Anderson and Gaddefors, 2017). 


\section{Entrepreneurship and Entrepreneurship Research}

Informed by the above position, entrepreneurship, can more appropriately be viewed as a contextual process of becoming (Steyaert, 1997; Anderson, 2005; Hjorth et al., 2015; Dey and Mason, 2018) "where the entrepreneur is continually learning and developing in relation to his or her business and the wider environment" (Cope, 2005b, p. 374). From this stance, we emphasise that entrepreneurship is predominantly grounded in the experience of entrepreneurs (Aggestam and Keenan, 2002; Stam, 2016).

However, we do not discard any other perspectives, such as economic (see Mole and Roper, 2012; Lerner et al., 2018) or psychological (see Miner, 2000; Kerr et al., 2017) and other possible truths that may exist. Our position of entrepreneurship underpins the argument that the exploration of how social actors make sense of their individual experience of entrepreneurial activities is a valid conduit of knowing (Packard, 2017; Newth, 2018; Fuller-Love and Akiode, 2020). This is vital given the diversity present within entrepreneurship and the demands for creativity and judgement in the face of unclear goals and uncertainty. Thus, a more comprehensive acknowledgement of the richness of lived experiences is particularly relevant to researching entrepreneurship (Leith et al., 2010; Berglund, 2015), which may not be fully appreciated if greater emphasis is placed on positivist approaches or on a few popular qualitative templates (Van Burg et al., 2020). In quantitative research, the richness of entrepreneurs' experience is narrowed down to limited variables; thus, entrepreneurship is approached partially and the wholeness and context are abandoned (Raco and Tanod, 2014). This diminishes in-depth understanding of the phenomenon as research seems to be driven in search of universal truths.

Despite the limitations of positivist approaches (Lincoln and Guba, 1985; Anderson and Starnawska, 2008), the field continues to be positivist dominant (Hlady-Rispal and JouisonLaffitte, 2014; McDonald et al., 2015; Eager et al., 2019; Marlow, 2020) focusing on objectivity and generalisability (Leitch et al., 2010). Consequently, there is low representation of interpretivist research (Downing, 2005; Fletcher, 2006; Packard, 2017; Kovalainen, 2018) with some evidence of growth and demand for more qualitative understanding (Bygrave, 1989; Gartner and Birley, 2002; Bygrave, 2007; Welter, 2011; Anderson and Jack, 2015; Neergaard and Leitch, 2015; Smith and McElwee, 2015; McDonald et al., 2015; Packard, 2017; Newth, 2018)). This has left space to develop a more balanced perspective of entrepreneurship, for example, by appreciating the 
contextual influences that appear to have been relatively overlooked due to complexity and perceptual issues (see Anderson and Gaddefors, 2017). Thus, we argue that IPA can address some of the weaknesses within qualitative research into entrepreneurship that are discussed below.

\subsection{Critiques on qualitative research in the field}

Valid critiques of qualitative research standards are also applicable to studies into entrepreneurship (see Neergaard and Ulhoi, 2007; Coviello, 2014). Weaknesses highlighted in the literature include lack of transparency; insufficient clarity on philosophical and methodological choices (HladyRispal and Jouison-Laffitte, 2014; Van Burg et al., 2020); "quick and dirty reduction" of data (Smith et al., 2009, p. 82) during data analysis, and obscurity of data analysis procedures (Smith and McKeever, 2015). In addition, studies that focus on phenomenology do not always fully justify their position (see Seymour, 2006) or, in general, establish an informed rationale as to why they claim to be phenomenological or qualitative (Hlady-Rispal and Jouison-Laffitte, 2014). These issues seem to influence many entrepreneurship researchers to be predominantly descriptive and insufficiently rigorous (Neergard and Ulhoi, 2007; Barredy, 2016).

Additionally, there is a tendency to perceive quality and validity of qualitative research from a positivist perspective (Smith and McKeever, 2015; Marshall et al., 2013) which restricts understanding of the importance and impact of qualitative research (Yardley, 2008). The conception that the meaning-making process is invisible in phenomenological research (Paley, 2017) is evident in some phenomenological inquiries into entrepreneurship (see sections 5.3). The literature (see Mawson and Kasem, 2019; Fuller-Love and Akiode, 2020) also emphasises the importance of exploring the personal experience of entrepreneurship. However, it is contestable whether we create sufficient space for personal experience to shine forth (see Packard, 2017) and encourage scholarly communities to be pluralistic in their research approach (Bygrave, 2007; Eager et al., 2019; Van Burg et al., 2020).

The issues highlighted above are not conclusive; however, such weaknesses result in criticism of the quality and trustworthiness of qualitative entrepreneurship research (see Smith and McKeever, 2015; Van Burg et al., 2020). This seems to have created a perceptual imbalance of the importance of quality of qualitative research over quantitative studies (Bygrave, 2007; Hlady-Rispal and Jouison-Laffitte, 2014). Consequently, scholarly confidence in initiating, conducting, and communicating qualitative studies is relatively limited, which seems to influence the above- 
mentioned reliance on a few popular templates, "overlooking the breadth of approaches qualitative research has to offer" (Van Burg et al., 2020, p. 02). Such reliance "greatly limits the power of qualitative research methods for discovery, exploration, and refinement" (Köhler et al., 2019, p. 03). These challenges should be addressed in entrepreneurship studies (Neergaard and Ulhoi, 2007; Kammerlander and De Massis, 2020) by considering variety of reliable methods "that enable different forms of analysis and offer the potential for novel theorising of entrepreneurship processes" (Van Burg et al., 2020, p. 02) in close interaction with contexts. This helps scholars to acknowledge that, personal practice of entrepreneurship is not universal and similar entrepreneurial processes can lead to different results and understanding (Welter, 2011).

It is also paramount that qualitative research is carried out with informed understanding of the applicable ontological, epistemological and methodological stances. This may help to address some of the perspectival issues related to rigour, quality and validity in qualitative research in entrepreneurship (Van Burg et al., 2020). To address some of these concerns, we introduce IPA and present theoretically informed justification for each methodological choice within the IPA research process with a detailed analytical procedure.

\section{IPA for Entrepreneurship Research}

IPA was introduced in 1996 by Professor Jonathan Smith as a psychological health research methodology informed by phenomenology, hermeneutics and idiography. It is becoming increasingly popular in many other disciplines (Wagstaff et al., 2014) as an established methodology. IPA is concerned with the lived experience of individual social actors (Jeong and Othman, 2016) to develop deeper understanding of a particular phenomenon (Larkin et al., 2018). Therefore, it has the potential to facilitate scholars' analysis of subjects' individual experiences (Wagstaff and Williams, 2014; Callary et al., 2015; Eatough and Smith, 2017); for example, running a startup, venture failures or success (see Cope, 2011). This paper clarifies that IPA focuses on 'being in the world' and the 'lived experience' (Larkin et al., 2011), and develops deeper qualitative understanding by focusing on how different stakeholders within entrepreneurship make sense of their experience (Davidsson, 2016; Aluthgama-Baduge and Rajasinghe, 2019). 
We re-emphasise that exploring how people give meaning to their experience is a valid way of knowing (Raco and Tanod, 2014) because "with due care and attention, interpretivist entrepreneurship research is capable of producing rich data though which respondents' experiences, perceptions and beliefs may be accessed, thus adding significantly to the understanding of entrepreneurial behaviour" (Leitch et al., 2010, p. 80). This appreciation of the importance of the context (Anderson, 2015) and the processual nature of entrepreneurship (Steyaert, 2007) can facilitate the understanding of, for example, complexities of entrepreneurial relationships, consciousness, how individuals evolve as entrepreneurs, and the unique issues they encounter, the actions and interactions, ups and downs and transformation of their identity (Leitch et al., 2010; Raco and Tanod, 2014; McKeever et al., 2015; Van Burg et al., 2020). These behaviours are "better understood within the industrial, geographical, personal, social, cultural, temporal and institutional domains in which it is embedded" (Neergaard and Leitch, 2015, pp. 12) by analysing how individuals, such as entrepreneurs, intrapreneurs, policy makers and scholars, make sense of their experiences of engaging in entrepreneurial activities (Newth, 2018; FullerLove and Akiode, 2020). This can help researchers to put aside their assumptions and allow themselves to understand entrepreneurship "personally, directly from the individual entrepreneurs" (Raco and Tanod, 2014, p. 283) and other actors of entrepreneurship.

IPA can facilitate entrepreneurship stakeholders to narrate their stories in their natural context (Steyaert, 1997), and give meaning to their experiences (Constantinidis et al., 2019). This helps scholars to appreciate that each entrepreneurial endeavour is a unique story (Blundel and Lockett, 2011), rather than a set of predefined or predictable patterns (Steyaert, 1997). Such exploration of what actually happens generates useful insights about the situated nature of entrepreneurship (Anderson and Starnawska, 2008; Raco and Tanod, 2014). This contextualisation of practice can lead to a more comprehensive understanding of the phenomenon (Leitch et al., 2010; Anderson, 2015; Steyaert, 2016; Packard, 2017) as it appreciates "uniqueness, heterogeneity, volatility and mundanity of entrepreneurial phenomena" (Van Burg et al., 2020, pp. 2-3).

IPA's interest in human experience and individual sense-making of that experience signifies the importance of both phenomenology and hermeneutics to deepen understanding because "without phenomenology there would be nothing to interpret; without hermeneutics, the phenomenon would not be seen" (Smith et al., 2009, p. 37). IPA is also idiographic as it focuses on how individual 
stakeholders of entrepreneurship place meaning into their experience (Larkin et al., 2011). This closely ties with Packard's (2017, p. 537) notion that "to understand entrepreneurship (...) we should begin at the foundation - with individual meaning and purpose". By focusing on individual meaning-making, scholars are able to fully appreciate that the "entrepreneur (...) is a complete and complex human being" (Berglund, 2015, p. 473) and that entrepreneurship is a contextual process of becoming (Steyaert, 2007; Gaddefors and Anderson, 2017). Therefore, IPA appears to be a useful approach to accommodate this complexity and diversity within entrepreneurship research, complemented by the presentation of rich theoretical and methodological guidance (Wagstaff et al., 2014; Rajasinghe, 2020). There is also an extensive global network of supportive experts willing to offer valuable input to scholars. The literature evidence suggests that following clear guidance for conducting an IPA study helps researchers to guarantee transparency within the research process and ensures quality and validity (Yardley, 2000; Smith, 2011; Willig, 2014).

The below sections further explore how exploration of human experience (phenomenology) and the way people give meaning to their experience (hermeneutics) help us to develop a deeper understanding of the phenomenon.

\subsection{Phenomenology}

Research methodology writers frequently position phenomenology as a philosophy, an approach, and a paradigm. The idea of phenomenology here is that it is the study of lived experience (Van Manen, 1997) through which meaning within a particular experience can be explored (Roberts, 2013).

The two main schools of phenomenology, descriptive and interpretative, form the basis of many philosophical interpretations (Gill, 2014). The philosophical literature on phenomenology is complex, thus, "it is easy to forget that its heart, the topic and approach of phenomenology does, or should, connect with our everyday experience" (Smith et al., 2009, p. 33). Therefore, whilst recognising the complexities and diversity of phenomenology (Steyaert, 2007; Paley, 2017), IPA appreciates the collective contribution of "scholars, such as Husserl, Merleau-Ponty, Heidegger and Sartre to develop a mature, multi-faceted, holistic phenomenology" (Smith et al., 2009, p. 34). IPA's interest lies in human lived experience and how individuals interpret their experience (Wagstaff et al., 2014; Jeong and Othman, 2016). Thus, IPA takes McLeod's (2001, p. 56) view that "understanding is always from a perspective, always a matter of interpretation". IPA scholars 
aim to conduct their studies "in a way which as far as possible enables that (...) individual experience to be expressed in its own terms, rather than according to predefined category systems" (Smith et al., 2009, p. 32), thus linking IPA's phenomenological stance to the core ideas of phenomenological philosophers. In turn, this echoes Berglund's (2015) notion of using phenomenological methods to develop new insights and Cope's (2005a) proposition of linking a specific form of phenomenological inquiry into the field, helping scholars to avoid the superficial mention that their study is 'phenomenological' or rushing to describe methodology, or the method sections of their studies (Seymour, 2006).

Following IPA as a research methodology also facilitates researchers to place first-hand experience of individual entrepreneurs at the forefront of their studies. For example, Cope's (2011) effort to understand how entrepreneurs learn from their failures by analysing the unique experience of individual entrepreneurs is commendable. The findings of this study provide policy makers with a deeper understanding of what actually happens within the research context, thereby facilitating the design of a specific support structure for the subjected entrepreneurs. Furthermore, appreciation of the situated, first-hand experience of individuals helps scholars to remain sensitive to the complexity and ambiguity of the phenomenon in different contexts (Berglund, 2015; Raco and Tanod, 2014) rather than reducing understanding to the existing theories (Berglund, 2007).

IPA's phenomenological stance facilitates researchers to avoid the tendency to lose sight of the meaning of participants' experience (see Paley, 2017). In most phenomenological studies, including entrepreneurship research, the meaning-making process is invisible (Paley, 2017). IPA addresses this by "laying out a sound theoretical basis for the meaning-making process (...) which ensures the transparency and traceability of studies" (Rajasinghe, 2020, p. 6). Therefore, IPA can be used to address some of these concerns when conducting qualitative studies in entrepreneurship. IPA also accepts the 'perceptual directedness' (Larkin et al., 2011); thus, there is no intention to separate contextual influences from the experience (Palmer et al., 2010). This complies with Gaddefors and Anderson's (2017, p. 273) notion that entrepreneurship "takes its shape from what it encounters and indeed, from how it encounters the element of context".

IPA considers the researcher as an active partner who co-creates understanding within the meaning-making process (Heidegger, 1962; Roberts, 2013). As Heidegger (1962) notes, individuals are immersed in culture, language, relationships, and events, and are broadly in the 
context. IPA's interest in analysing situated personal experience is promoted by many entrepreneurship scholars (see Cope, 2011; Raco and Tanod, 2014; Anderson, 2015; Newth, 2018) but gaps in idiographic focus, methodological plurality and analytical transparency (see for example Berglund, 2007; Van Burg et al., 2020) and providing sufficient space for the individual experiential accounts continues, with some obvious exceptions. Thus, IPA's focus on human experience to develop understanding, detailed attention to individual experiential accounts and contextual sensitivity, position it as a good methodology to explore some timely questions that can facilitate progress without reducing entrepreneurship to a mechanistic process.

\subsection{Hermeneutics}

Hermeneutics is the theory of interpretation (Rodham et al., 2015). As previously argued, IPA appreciates both the researcher's and the participant's role in making sense of the participant experience. In IPA, interpretation is seen as vital to develop deeper understanding (Clancy, 2013). "For Heidegger and IPA, unlike some other phenomenologies, to do the phenomenology you need to do the hermeneutics, you need to do the interpretation" (Smith, 2018, p. 6). This confirms that "there is phenomenon (...) (entrepreneurship) ready to shine forth, but detective work is required by the researcher to facilitate coming forth, and then to make sense of it once it has happened" (Smith et al., 2009, p. 34). Thus, IPA accepts that our (e.g. scholars' and practitioners') understanding is transpired through socially, culturally and historically mediated interpretations (Pernecky and Jamal, 2010). Such acceptance is vital for entrepreneurship research if contextually embedded meaning is to be explored (Leith et al., 2010; Gaddefors and Anderson, 2017).

Ricoeur (1970) argues that the interpretation supports the restoration of the meaning of an experience, introducing two schools of hermeneutics, namely: hermeneutics of empathy and hermeneutics of suspicion (see Ricoeur, 1970; Willig, 2014). IPA places itself within the centreground of these two concepts, following hermeneutics of empathy and hermeneutics of questioning (Smith et al., 2009). These authors argue that the empathetic hermeneutics helps to see the experience from the lens of the participant (insider perspective) and the questioning hermeneutics facilitates deeper understanding of the phenomenon. IPA discards the hermeneutics of suspicion which would bring an outside perspective, such as in psychoanalysis, to our understanding (Willig, 2014). Therefore, in IPA, the interpretations are always grounded in the experience of the participant (Wagstaff et al., 2014). This complies with Packard's (2017) notion of returning to 
individual meaning and purpose to understand entrepreneurship, and Hjorth et al.'s (2015) and Steyaert's $(1997$; 2007) view of entrepreneurship as a contextual process of becoming.

Apart from the above modes of interpretation, IPA acknowledges the researcher's role in the meaning-making process, where the researcher makes sense of the participant's interpretation of their experience (double hermeneutics) (Larkin et al., 2011; Jeong and Othman, 2016). It is natural to understand something by engaging in a dialogue with the person who has experienced the event. This naturalistic understanding is important for entrepreneurship (Dana and Dana, 2005) to safeguard the richness of the phenomenon (Dana and Dana, 2005; Raco and Tanod, 2014).

The combination of both phenomenology and hermeneutics deepens our understanding without muting the complexities of entrepreneurship (Steyaert and Katz, 2004; Berglund and Johansson, 2007; Anderson and Gaddefors, 2017). However, to develop more critical and informed understanding of these concepts and their relevance, readers should continue to reflect on our position of entrepreneurship. This possibly facilitates scholars to make informed choices in their phenomenological research decisions leading to the development of new insights into entrepreneurship (Berglund, 2015). In addition, clarity on philosophical underpinnings will address the highlighted issue of avoiding "the mire of philosophy (...) and skip straight to discussion of methodology or method" (Seymour 2006, p. 137). It can also help scholars to develop literature-informed rationale for adopted philosophies in entrepreneurship research (for example, see Kempster and Cope, 2010; Cope, 2011).

\section{IPA Study Designs}

IPA studies aim to deepen understanding of a particular phenomenon and also focuses on analysing perceptions and views of participants (Palmer et al., 2010). These "trends reflect both phenomenological and interpretative aspects of IPA" (Smith et al., 2009, p. 46). IPA's open approach to knowing is further obvious with the use of verbs that describe the "researchers' actions and intentions in relation to their chosen objects of interest" with 'exploring' being the most common, and 'investigating', 'examining' and 'eliciting' being other alternatives (Smith et al., 2009, p. 46).

With this focus of knowing, and informed by an inductive approach, IPA researchers tend to ask questions such as: how people make sense of their experience of venture failures (see Cope, 2011); 
experience of learning to lead (see Kempster and Cope, 2010); and experience of coping with anxiety (see Gill, 2015). IPA also promotes developing an understanding of how entrepreneurship stakeholders think about issues such as profit making and social contribution, and how their sense of identity changes during transitions (Smith et al., 2009), for example from being employed to becoming an entrepreneur. These potentials within IPA link well with the central interests of entrepreneurship research, e.g. actions and identities of individual entrepreneurs (see Berglund, 2015), contextual relevance of our understanding (Anderson and Gaddafors, 2017) and consciousness that drives individuals to become entrepreneurs (Raco and Tanod, 2014). IPA's strong idiographic nature also complements the notion of focusing on individual experience of entrepreneurs (Kempster and Cope, 2010). The above-cited IPA studies in entrepreneurship evidence scholarly confidence on how IPA can be utilised to deepen understanding of entrepreneurs' life world.

The primary questions that IPA addresses are further evidence IPA's openness and innovative nature as a research methodology which does not encourage a fixed study design. However, many studies explore a particular experience from a single perspective (e.g. entrepreneurs or educators), by conducting one semi-structured interview with each participant from a small homogenous sample (Larkin et al., 2018). Despite the popularity of this simple design, some authors (see Wagstaff et al., 2014; Larkin et al., 2018) encourage scholars to innovate within the methodology. For instance, there is a growing tendency within IPA research to develop bolder designs. Spiers et al.'s (2016) longitudinal study conducts three interviews with each participant; Clare (2003) explores multiple perspectives and conducts two interviews with each participant. Furthermore, a limited number of studies (e.g. Clare, 2002; Larkin and Griffiths, 2004; Barr and McConkey, 2007; Wagstaff and Williams, 2014) deviate from Smith et al.'s (2009) notion of simple IPA design. These studies provide some justification for entrepreneurship scholars to inform their innovative approaches to research design, for instance, exploring diverse stakeholders' perspectives and by acknowledging that each social actor can have an equally valid interpretation of the phenomenon (see Van Burg et al., 2020). These designs can facilitate a deeper understanding of complex issues of entrepreneurship (Hlady-Rispal and Jouison-Laffitte, 2014) compared to common descriptive approaches, such as thematic analysis (Brocki and Wearden, 2006; Holloway and Todres, 2003). 
With experience of conducting IPA studies with bolder designs, we emphasise the importance of justifying the appropriateness of the bolder design by reflecting on the aims and objectives of a particular study. For example, the first author conducted two interviews with each study participant (see Rajasinghe, 2018) in order to deepen the understanding of the individual's experience (see Clare, 2003) and explored both coachees' and coaches' perspectives in order to understand how coaching helps coachee development. The analysis of both perspectives and the conducting of two interviews are considered to be internal reliability checks (Jeong and Othman, 2016) and an opportunity to develop deeper understanding without restricting the study to a single perspective (see Elliot et al., 1999; Larkin et al., 2018).

These possibilities show that IPA can be a valuable inclusion for entrepreneurship research to address some of the challenges of conducting qualitative studies, such as having shallow justification of choices and lack of innovative research approaches and perspectives (see HladyRispal and Jouison-Laffitte, 2014; Van Burg et al., 2020).

\subsection{Sampling Strategy, Sample Size}

Sampling should be "theoretically consistent with the qualitative paradigm in general, and with IPA in particular" (Smith et al., 2009, p. 48) to ensure quality outcomes from studies. The validity of qualitative research lies in rich, in-depth qualitative data generated by selected participants for a specific purpose (Gray, 2014). Sampling in qualitative research aims to achieve 'phenomenon representation' over 'population representation' (Gray, 2014); attempting the latter is considered inappropriate within the qualitative research tradition and in IPA (Marshall et al., 2013; Smith et al., 2009). IPA's focus on a particular experience shared by social actors demands a homogeneous sample (Pietkiewicz and Smith, 2012; Roberts, 2013; Wagstaff et al., 2014). Cope (2011) positioned this sampling strategy for IPA studies as a highly credible and relevant approach in order to understand the experiences of entrepreneurial failures and facilitated the development of a competent theoretical perspective of the phenomenon. However, comprehensive homogeneity is not practical due to the diversity within individuals (Clarke, 2009; Roberts, 2013).

Once the homogeneity criterion is decided, the researcher should focus on participant numbers. There is a general tendency to look for large samples due to the positivist influence (Gray, 2014). However, for an IPA study, a small sample size helps the researcher to deeply explore each 
participant experience (Eatough and Smith, 2017; Rajasinghe, 2020). Therefore, the appropriate sample size for an IPA project is the number that answers the research question. Some (Smith and Eatough, 2007; Gray, 2014) endorse this idea by highlighting the possibility of choosing a single case $(\mathrm{N}=1)$ for specific reasons which "is indeed a logical step if the idiographic project is taken seriously" (Smith and Eatough, 2007, p. 39).

Therefore, the absence of randomisation and large samples in IPA is justifiable because they are "constructs of positivist tradition" (Hennink et al., 2011, p. 8). Focusing on statistical representation erodes the foundation and rationale of qualitative research (Yardley, 2000) with no exception for IPA. Hence, the sample sizes for IPA studies should be relatively small (Roberts, 2013), thereby enabling the development of a "detailed account of individual experience" (Smith et al., 2009, p. 51).

\subsection{Data Collection}

The "data collection is usually (but not necessarily) in the form of semi-structured interviews" (Smith et al., 2009, p. 4), which is the widely used method (Reid et al., 2005; Pietkiewicz and Smith, 2012). The aim is to "elicit detailed stories, thoughts and the feelings" (Smith et al., 2009, p. 57) of participants. To obtain rich, detailed, first-hand experience (Pietkiewicz and Smith, 2012), participants must be allowed sufficient space to express their concerns at length (Callary et al., 2015). For example, Cope (2011, p. 610) approaches data collection without bringing theory informed priori understanding just by asking "can you tell me about your experience of having a venture that has not succeeded?" and constructing subsequent questions from the dialogue. Therefore, despite some evidence of focus groups, diaries and observation-like methods being employed in IPA studies, semi-structured interviews are accepted (see Smith and Osborn, 2008) as a good initial step for novice scholars. Interview skills development, enhancing rapport with participants, providing sufficient space for the participants with minimal disruptions, and carrying out pilots can ensure quality, validity and relevance of the data. 


\subsection{Data Analysis}

Data analysis is critical to improve the robustness and trustworthiness of qualitative entrepreneurship research, particularly by demonstrating quality and rigour through a careful and comprehensive analysis process (Leitch et al., 2010). IPA's data analysis should be consistent with its theoretical underpinnings (Jeong and Othman, 2016). In itself, this is a way of ensuring the quality of qualitative research (Yardley, 2000; 2008) by not merely mentioning the philosophical positions for a particular study but by continuing to demonstrate how these positions shape our research decisions, for example data collection and analysis.

During the analysis process, the researcher should attempt to provide full appreciation of the firsthand experience of each participant (Raco and Tanod, 2014) thereby facilitating the development of a contextually embedded unique deeper understanding of the phenomenon (see section 4). In doing so, IPA scholars employ both empathetic and questioning hermeneutics. Similar to other types of qualitative data analysis, IPA's data analysis is also bottom up, and is thus inductive (Gray, 2014). However, the IPA data analysis helps entrepreneurship scholars to avoid a narrow focus on developing some descriptive themes due to its philosophically-underpinned (i.e., phenomenology, hermeneutics, and idiography) approach to data analysis (Brocki and Weaden, 2006).

Many IPA scholars claim that a prescribed way of data analysis does not exist, emphasising that the methodology encourages innovation and creativity. However, evidence suggests that most IPA studies follow Smith et al. 's (2009) guidance which seems to ensure transparency and quality of data analysis (Smith, 2011), thus helping researchers to conduct a rigorous analysis. For instance, we notice Cope's (2011) IPA study has a notable transparency of data analysis over Hemme et al. 's (2017) phenomenological inquiry of entrepreneurs' experience. Therefore, we argue that the clearly laid out guidance enhances qualitative researchers' scholarly confidence and transparency of the research process (Rajasinghe, 2020). Therefore, we briefly discuss Smith et al. 's (2009) data analysis process, linking theory and our practical experience of conducting IPA studies. However, we emphasise that IPA “does not seek to claim objectivity through the use of a detailed, formulaic procedure" (Brocki and Wearden, 2006, p. 97) and these guidelines should be seen as one way of explication of many possible means to analyse IPA data (Pietkiewicz and Smith, 2012). 


\section{- Step 1: Reading and re-reading}

Kempster and Cope (2010) present this first stage as 'reading of the case', which involves reading and re-reading the transcript whilst listening to the recorded voices of individual participants (Smith et al., 2009). It is claimed that the analysis starts during the transcription phase (see Kent and Potter, 2014) and continues until the write up is complete (Smith et al., 2009). Continuous listening, reading and re-reading of the transcripts helps the researcher to be closer to the participants' experience and to enter into the participant's world, thus facilitating deeper understanding of each participant's experience (Rodham et al., 2015). The continuous engagement with the transcripts and recordings helps to make the participant central to the analysis and to "slow down our habitual propensity for quick and dirty reduction and synopsis" (Smith et al., 2009, p. $82)$.

\section{- Step 2: Initial noting}

This phase explores "semantic content and language use" (Smith et al., 2009, p. 83). Analysts are encouraged to write down anything of interest about the phenomenon which ensures increasing familiarity with the participant experience. The aim is to produce a set of detailed notes and comments on the transcript, where the immersion and sense-making of data begin (Jeong and Othman, 2016). In this phase, line-by-line detailed attention is given to the participant experience; therefore, the comments have a clear phenomenological focus. Along with these comments, "more interpretative noting helps (...) scholars to understand how and why (...) their participant has these concerns" (Smith et al., 2009, p. 83). This involves exploring the participant's use of language and their lived world. The researcher is involved in describing (Eatough and Smith, 2017) and interrogating (Shinebourne, 2011) the participant's experience; thus, questioning and empathetic hermeneutics help to deepen the understanding (Rajasinghe, 2020). At this stage, the analyst uses different techniques, such as different colour codes or columns, to identify units of meaning and groups them into common clusters (see Kempster and Cope, 2010; Aluthgama-Baduge, 2017). 


\section{- Step 3: Developing emergent themes}

Here, the researcher develops emergent themes by capturing the essence of the initial notes and continuing to employ questioning and empathetic hermeneutics (Fade, 2004). This helps to develop a more interpretative account of the participant experience (Reid et al., 2005) by moving away from the original transcript and focusing more on initial comments (Brocki and Wearden, 2006). However, it is important that the analyst continues to reflect on the importance of 'I' and 'P' in IPA (see Smith et al., 2009). Melis et al., (2020); for example, to emphasise the importance of ensuring idiographic commitments and how such initiatives facilitate substantial space for researchers to deepen participants' life world by allowing the phenomenon to shine forth through interpretative engagement.

This process is one "manifestation of the hermeneutics circle (...) where the original whole of the interview becomes a set of parts as you conduct your analysis, but these then come together in another new whole at the end of the analysis" (Smith et al., 2009, p. 91). It is recognised that the analyst moves between the whole (interview transcripts) and the parts (emergent themes) to understand the participant's sense-making.

\section{- Step 4: Searching for connections across emergent themes}

This step involves finding the connections across the emergent themes within the case (Melis et al., 2020). The analyst may transfer emergent themes into a separate document and cluster them with associated themes (Jeong and Othman, 2016; Rajasinghe, 2018). The process involves techniques such as abstraction (putting like with like and developing a new name for the cluster), submission (an emergent theme that itself claims to be a superordinate theme), contextualisation (trying to identify contextual and narrative elements) and numeration (the frequency with which a theme is supported) (see Smith et al., 2009; Rajasinghe, 2018). By ensuring the iterative process of data analysis, the researcher re-visits the emergent themes and previous stages, thereby ensuring that the themes are grounded in participant experience and the traceability and transparency of data analysis (Yardely, 2000; Shinebourne, 2011) leading to addressing some of the gaps in qualitative entrepreneurship research highlighted earlier in this paper. 


\section{- Step 5: Moving to the next case}

Completion of the first four stages of the analysis process means that these steps recur separately with each case (Melis et al., 2020), in line with IPA's idiographic commitments (Smith and Eatough, 2007). One of the challenges here is to avoid being informed by the previous case analysis. Smith et al., (2009, p. 100) emphasise the importance of "treating (...) the next case on its own terms, to do justice to its own individuality" by bracketing the ideas that emerged from the previous case.

We suggest that the analyst should endeavour to immerse him/herself in data (next case) through continuous listening, reading and re-reading rather than attempting mechanical efforts at bracketing, thereby helping to place more emphasis on the "positive process of engaging with the (...) data than the process of bracketing prior concerns, in the sense that the skillful attention to the former inevitably facilitates the latter" (Smith et al., 2009, p. 35). Having a break in between each case analysis may also facilitate further distancing from the previous case (Rajasinghe, 2018). However, IPA accepts that the researcher will inevitably be influenced by what has already been found (Wagstaff and Williams, 2014). The attempt here is to provide the fullest appreciation possible of the participant experience. (Shinebourne, 2011).

\section{- Step 6: Looking for patterns across cases}

This phase involves exploring themes across cases for convergences and divergences. Referring back to the research question at this stage is vital in finalising super-ordinate themes for the study. This exercise can involve reconfiguring and/or re-labelling superordinate themes. The data have been subjected to several levels of interpretations by now (Pietkiewicz and Smith, 2012) and this interpretative engagement will continue until writing up the findings is complete, resulting in a "detailed account of patterns of meaning and reflections on shared experience" (Shinebourne, 2011, p. 23).

IPA acknowledges that the findings are positioned in the participants' "experience, their culture, language and locale" (Smith et al., 2009, p. 195). Therefore, to help make sense of the findings, it is important that the analyst provides sufficient understanding of the context of the research, the participants and the researcher. We invite scholars to present "findings in a manner that is 
engaging, coherent and accessible" (Gray, 2014, p. 632) to make the study meaningful to a wider audience because the analysis "is of no value unless your reader can make some sense of it too!" (Smith et al., 2009, p. 109).

This explanation of how to conduct an IPA data analysis may help researchers to ensure the quality of studies and address the issue of providing "insufficient detail (...) regarding methodology or the way data were analysed" (Hlady-Rispal and Jouison-Laffitte, 2014, p. 610) in qualitative entrepreneurship research.

\section{Quality and Validity}

Researchers should place emphasis on selecting an appropriate quality criterion for qualitative research (Flick, 2014) without delving into long existing positivist dominance in human thinking and practice (Marshall et al., 2013). It is important to employ a criterion in line with IPA's philosophical positions. Smith et al. (2009) suggest Yardley's (2000; 2008) and Elliot et al.'s (1999) quality criteria as being appropriate for IPA studies. Furthermore, Smith (2011) developed a criterion specifically for IPA studies. We endorse Smith et al. 's (2009) claim on the qualityembedded nature of IPA studies with clear guidance from designing a project to writing up. The set guidelines closely linked with criteria that Yardley (2008), Elliot et al., (1999) and Smith (2011) present confirm the quality orientation of IPA from scratch. However, "the criteria espoused by (...) these authors may be interpreted differently by different authors" (Rajasinghe, 2020, p. 185), thus the decision about the appropriate quality criteria is subjective (Flick, 2014). The quality consciousness of IPA presents an opportunity for scholars to address some of the concerns in conducting qualitative studies in entrepreneurship. For instance, the developed clarity may help to address Hlady-Rispal and Jouison-Laffitte's (2014, p. 611) call for entrepreneurship scholars to be "more transparent in their methods and the justifications for their choices (sampling, data gathering, and especially data analysis)", and Neergaard and Leitch's (2015) encouragement to ensure trustworthiness and rigour in entrepreneurship research. 


\section{Limitations of IPA}

IPA has limitations upon which researchers should reflect as they explore its relevance and potential for entrepreneurship research. Having a primary focus of developing subjective understanding does not concur with the positivist viewpoints but qualitative research is not there to satisfy positivist expectations (Marshall et al., 2013). For instance, findings of an IPA study cannot be generalised if researchers seek statistical-probabilistic generalisability. However, scholars should explore possibilities of other types of generalisations, such as 'naturalistic', 'transferability' and 'concept or theoretical', which are in line with the philosophical underpinnings of qualitative research (see Smith, 2018), including IPA.

It is important to allow readers to make sense of the findings which may result in different interpretations that are equally valid (see Yardley, 2008). The readers' role in hermeneutic dialogue is recognised in IPA, so the interpretation of findings from the readers' perspective should not be considered as misinterpretation, although this is a likely outcome, at least in positivist minds. IPA researchers should be reflexive, reflective and transparent throughout the research process in order to ensure that readers are provided with adequate information regarding the study context, the researcher and the researched.

IPA relies on semi-structured interviews and participants' ability to interpret their experience, hence factors such as language skills and cultural background may play a role in the ability of participants to interpret their experience, which may be seen as a limitation. However, sharing experience through language is a natural way of sense-making and IPA acknowledges that interpretations are "shaped, limited and enabled by language" (Smith et al., 2009, p. 194) and culture. There is also a possibility of self-reported bias in the collected data (Berg and Karlsen, 2012); however, self-reported biases are part of the lived-world. IPA's acknowledgement of perspectival directedness (see Larkin et al., 2011) can appear as an advantage to capture diverse perspectives of, for example, the entrepreneurial process, and entrepreneurs' consciousness and learning, which are culturally and socially influenced.

Data collection, transcribing and analysis in line with idiographic commitments are timeconsuming. The number of participants within a study makes a significant difference, thus researchers are reminded that, sometimes 'less is more' 


\section{Conclusion}

There are some positive signs of development in qualitative research within entrepreneurship. However, there are also some challenges that should be addressed in order to enhance researchers' scholarly confidence. The paper encourages scholars to develop theoretically informed research decisions by suggesting IPA as an appropriate research methodology. The arguments established here aim to encourage entrepreneurship scholars who are particularly interested in phenomenology, hermeneutics and idiography to explore the potential of using IPA to develop fuller appreciation and understanding of the field. Entrepreneurship scholars may find this paper useful to ensure transparency, rigorous analysis, and quality and validity of research. The clear guidance set out in the paper may also be appealing to researchers from other disciplines to develop their understanding of IPA as a qualitative research methodology. In promoting IPA and subjective

understanding in entrepreneurship, we do not discard other possible modes of knowing and realities but encourage diversity, pluralism and inclusivity in research perspectives. 


\section{References}

Aggestam, M. and Keenan J. (2002), "Entrepreneurial Act as Languaging, Languaging as Entrepreneurial Act", Paper presented at the ESBRI New Practices of Entrepreneurship Workshop, Stockholm, Sweden, May 23-26.

Aluthgama-Baduge, C.J. (2017), Educating for enterprise: Exploring the role of the teacher. An Interpretative Phenomenological Analysis, PhD Thesis, Abertay University, Dundee, UK.

Aluthgama-Baduge, C. and Rajasinghe, D. (2019), "Developing Graduate Entrepreneurs: Exploring the Experiences of University Entrepreneurs in Residence”, working paper, University Forum for Human Resource Development (UFHRD) Conference 2019, 24-26 June, Nottingham Business School, Nottingham, pp.17-27.

Anderson, A.R. (2005), "Enacted metaphor: The theatricality of the entrepreneurial process", International Small Business Journal, Vol. 23 No. 6, pp.587-603.

Anderson, A.R. (2015), “Conceptualising entrepreneurship as economic 'explanation' and the consequent loss of 'understanding'”, International Journal of Business and Globalisation, Vol. 14 No. 2, pp.145-157.

Anderson, A.R. (2016), "The economic reification of entrepreneurship: re-engaging with the social", in Fayolle A. and Riot. P. (Ed.s), Rethinking Entrepreneurship: Debating research orientations, Routledge, Oxon, pp.44-56.

Anderson, A.R. and Gaddefors, J. (2017), “Is Entrepreneurship Research out of Context?”, Journal of Asia Entrepreneurship and Sustainability, Vol. 13 No. 4, pp.3-9. 
Anderson, A.R. and Jack, S.L. (2015), "An introduction to the constant comparative technique". in Neergaard, H., and Leitch. C.M., (Ed.s), Handbook of Qualitative Research Techniques and Analysis in Entrepreneurship, Edward Elgar, Cheltenham, pp.15-20.

Anderson, A.R. and Starnawska, M. (2008), "Research Practices in Entrepreneurship", The International Journal of Entrepreneurship and Innovation, Vol. 9 No. 4, pp.221-230.

Barr, O. and McConkey, R. (2007), "A different type of appointment: the experiences of parents who have children with intellectual disabilities referred for genetic investigation", Journal of Research in Nursing, Vol. 12 No.6, pp.637-652.

Barredy, C. (2016), "Typology of interactions and data content in qualitative family case study research", in Randerson, et al., (Ed.s), Family entrepreneurship rethinking the research agenda, Routledge, London, pp.279-301.

Berg, M.E. and Karlsen, T.J. (2012), "An evaluation of management training and coaching", Journal of Workplace Learning, Vol. 24 No.3, pp.177-199.

Berglund, H. (2007), "Opportunities as existing and created: a study of entrepreneurs in the Swedish mobile internet industry," Journal of Enterprising Culture, Vol. 15 No. 3, pp.243-273.

Berglund, H. (2015), "Between cognition and discourse: Phenomenology and the study of entrepreneurship", International Journal of Entrepreneurial Behaviour and Research, Vol 21 No. 3, pp.472-488.

Berglund, K. and Johansson, A.W. (2007), "Entrepreneurship, discourses and conscientization in processes of regional development", Entrepreneurship and Regional Development, Vol. 19 No. 6, pp.499-525. 
Blundel, R. and Lockett, N. (2011), Exploring entrepreneurship: Practices and Perspectives, Oxford University Press, Oxford.

Brannback, M. and Carsrud, A.L. (2016), “Understanding entrepreneurial cognitions through the lenses of context", in Welter F. and Gartner W.B. (Ed.s), A Research Agenda for Entrepreneurship and Context, Edward Elgar, Cheltenham, pp.16-27.

Brocki, J.M. and Wearden, A.J. (2006), "A critical evaluation of the use of interpretative phenomenological analysis (IPA) in health psychology", Psychology and Health, Vol. 21 No. 1, pp.87-108.

Bygrave, W.D. (1989), “The entrepreneurship paradigm (I): A philosophical look at its research methodologies", Entrepreneurship Theory and Practice, Vol. 14 No. 1, pp.7-26.

Bygrave, W.D. (2007), "The entrepreneurship paradigm (I) revisited", in Neergaard, H. and Leitch. C.M. (Ed.s), Handbook of Qualitative Research Techniques and Analysis in Entrepreneurship, Edward Elgar, Cheltenham, pp.17-48.

Callary, B., Rathwell, S. and Young, B.W. (2015), "Insights on the process of using interpretive phenomenological analysis in a sport coaching research project", The Qualitative Report, Vol. 20 No. 2, pp.63-75.

Chell, E. (2013), "Review of skill and the entrepreneurial process", International Journal of Entrepreneurial Behaviour \& Research, Vol. 19 No. 1, pp.6-31.

Clancy, M. (2013), "Is reflexivity the key to minimizing problems of interpretation in phenomenological research?", Nursing Research, Vol. 20 No. 6, pp.2-16. 
Clare, L. (2002), "We'll fight it as long as we can: coping with the onset of Alzheimer's disease", Journal of Aging \& Mental Health, Vol. 6 No. 2, pp.39-148.

Clare, L. (2003), "Managing threats to self: awareness in early-stage Alzheimer's disease", Social Science \& Medicine, Vol. 57 No. 6, pp.1017-1029.

Clarke, C. (2009), "An introduction to interpretative phenomenological analysis: A useful approach for occupational therapy research", The British Journal of Occupational Therapy, Vol. 72 No. 1, pp.37-39.

Constantinidis, C., Lebegue, T., Abboubi, M. E. and Salman, N. (2019), "How families shape women's entrepreneurial success in Morocco: an intersectional study", International Journal of Entrepreneurial Behaviour and Research, Vol. 25 No. 8, pp.1786-1808.

Cope, J. (2005a), "Researching Entrepreneurship through Phenomenological Inquiry: Philosophical and Methodological Issues”, International Small Business Journal, Vol. 23 No. 2, pp.163-189.

Cope, J. (2005b), "Toward a dynamic learning perspective of entrepreneurship", Entrepreneurship: Theory and Practice, Vol. 29 No. 4, pp.373-397.

Cope, J. (2011), "Entrepreneurial learning from failure: An interpretative phenomenological analysis", Journal of Business Venturing, Vol. 26(6), pp.604-623.

Coviello, N. (2014), "How to Publish Qualitative Entrepreneurship Research in Top Journals," in Fayolle, A. and Wright, M. (Ed.s.), How to Get Published in the Best Entrepreneurship Journals: A Guide to Steer Your Academic Career, Edward Elgar, Cheltenham, pp.167-182. 
Dana, L.P. and Dana, T.E. (2005), "Expanding the scope of methodologies used in entrepreneurship research", International Journal of Entrepreneurship and Small Business, Vol. 2 No. 1, pp.79-88.

Davidsson, P. (2016), Researching Entrepreneurship: Conceptualization and Design. $2^{\text {nd }}$ ed, Springer, Cham Heidelberg.

Dey, P. and Mason, C. (2018), "Overcoming constraints of collective imagination: An inquiry into activist entrepreneuring, disruptive truth-telling and the creation of "possible worlds"', Journal of Business Venturing, Vol. 33 No. 1, pp.84-99.

Downing, S. (2005), "The social construction of entrepreneurship: Narrative and dramatic processes in the coproduction of organizations and identities", Entrepreneurship Theory and Practice, Vol. 29 No. 2, pp.185-204.

Eager, B., Grant, S. and Maritz, A. (2019), "Classifying coping among entrepreneurs: is it about time?", Journal of Small Business and Enterprise Development, Vol. 26 No. 4, pp.486-503.

Eatough, V. and Smith, J.A. (2017), "Interpretative Phenomenological Analysis", in C. Willig and W. Stainton-Rogers (Ed.s), The Sage Handbook of Qualitative Research in Psychology, $2^{\text {nd }}$ ed., Sage, London, pp.193-211.

Elliott, R., Fischer, C.T. and Rennie, D.L. (1999), "Evolving guidelines for publication of qualitative research studies in psychology and related fields", British Journal of Clinical Psychology, Vol. 38 No. 3, pp.215-229.

Fade, S. (2004), "Using interpretative phenomenological analysis for public health nutrition and dietetic research: a practical guide", Proceedings of the Nutrition Society. Vol. 63 No. 4, pp.647653. 
Fletcher, D.E. (2006), "Entrepreneurial processes and the social construction of opportunity", Entrepreneurship and Regional Development, Vol. 18 No. 5, pp.421-440.

Flick, U. (2014), An introduction to qualitative research, $5^{\text {th }}$ ed, Sage, London.

Fuller-Love, N. and Akiode, M. (2020), "Transnational Entrepreneurs Dynamics in Entrepreneurial Ecosystems: A Critical Review", Journal of Entrepreneurship and Innovation in Emerging Economies, Vol. 6 No. 1, pp.41-66.

Gaddefors, J. and Anderson, A. (2017), "Entrepreneursheep and context: when entrepreneurship is greater than entrepreneurs", International Journal of Entrepreneurial Behaviour and Research, Vol. 23 No. 2, pp.267-278.

Gartner, W.B. and Birley, S. (2002), "Introduction to the Special Issue on Qualitative Methods in Entrepreneurship Research”, Journal of Business Venturing, Vol. 17 No. 5, pp.387-395.

Gill, M.J. (2014), "The possibilities of phenomenology for organizational research." Organizational Research Methods, Vol. 17 No. 2, pp.118-137.

Gill, M.J. (2015), “Elite identity and status anxiety: An interpretative phenomenological analysis of management consultants", Organization, Vol. 22 No. 3, pp.306-325.

Gray, D.E. (2014), Doing Research in the Real World, $3^{\text {rd }}$ ed. Sage Publication Ltd., London.

Heidegger, M. (1962), Being and time, Macquarrie, J. and Robinson, E. (Trans), Wiley-Blackwell, London.

Hemme, F., Morais, D.G., Bowers, M.T. and Todd, J.S. (2017), "Extending sport-based entrepreneurship theory through phenomenological inquiry", Sport Management Review, Vol. 20 No. 1, pp.92-104. 
Hennink, M., Hutter, I. and Bailey, A. (2011), Qualitative research methods, Sage, London.

Hjorth, D., Holt, R. and Steyaert, C. (2015), “Entrepreneurship and process studies”, International Small Business Journal: Researching Entrepreneurship, Vol. 33 No. 6, pp.599-611.

Hlady-Rispal, M. and Jouison-Laffitte, E. (2014), "Qualitative research methods and epistemological frameworks: A review of publication trends in entrepreneurship", Journal of Small Business Management, Vol. 54 No.4, pp.594-614.

Holloway, I. and Todres, L. (2003), “The status of method: flexibility, consistency and coherence”, Qualitative Research, Vol. 3 No. 3, pp.345-357.

Jeong, H. and Othman, J. (2016), "Using interpretative phenomenological analysis from a realist perspective", The Qualitative Report, Vol. 21 No.3, pp.558-570.

Kammerlander, N. and De Massis, A. (2020), "Frequently asked questions in qualitative family business research and some guidelines to avoid risky paths", in De Massis, A. and Kammerlander, N. (Ed.s), Handbook of qualitative research methods for family business, Edward Elgar, Cheltenham, pp.1-24.

Kempster, S. and Cope, J. (2010), "Learning to lead in the entrepreneurial context", International Journal of Entrepreneurial Behaviour \& Research, Vol. 16 No. 1, pp.05-34.

Kent, A. and Potter, J. (2014), "Discursive Social Psychology", in T. M. Holtgraves (Ed.s), The Oxford Handbook of Language and Social Psychology, Oxford University Press, New York, pp.295-314.

Kerr, S.P., Kerr, W.R., and Xu, T. (2017), "Personality Traits of Entrepreneurs: A Review of Recent Literature”, working paper 18-047, Harvard Business School, Boston, MA, November 2017. 
Köhler, T., Smith, A., and Bhakoo, V. (2019), "Feature Topic for ORM: Templates in Qualitative Research Methods”, Organizational Research Methods, Vol. 22 No. 1, pp.3-5.

Kovalainen, A. (2018), “Qualitative Research in Entrepreneurship”, in Blackburn, R., Clercq, D.D. and Heinonen, J. (Ed.s), The Sage Handbook of Small Business and Entrepreneurship, Sage Publication Ltd. London, pp.542-559.

Larkin, M. and Griffiths, M.D. (2004), "Dangerous sports and recreational drug-use: rationalizing and contextualizing risk", Journal of Communication and Applied Social Psychology, Vol. 14 No. 4, pp.215-232.

Larkin, M., Eatough, V. and Osborn, M. (2011), "Interpretative phenomenological analysis and embodied, active, situated cognition”, Journal of Theory \& Psychology, Vol. 21 No.3, pp.318-337.

Larkin, M., Shaw, R. and Flowers, P. (2018), "Multiperspectival designs and processes in interpretative phenomenological analysis research", Qualitative Research in Psychology, Vol. 16 No. 2, pp.182- 198

Leitch, C.M, Hill, F.M. and Harrison, R.T. (2010), "The Philosophy and practice of interpretivist research in entrepreneurship: Quality validity and trust", Organizational Research Methods, Vol.13 No.1, pp.67-84.

Lerner, D. A., Hunt, R. A. and Dimov, D. (2018), "Action! Moving beyond the intendedly-rational logics of entrepreneurship", Journal of Business Venturing, Vol.33 No.1, pp.52-69.

Lincoln, Y.S. and Guba, E.G. (1985), Naturalistic Inquiry, SAGE, London.

Marlow, S. (2020), "Gender and entrepreneurship: past achievements and future possibilities", International Journal of Gender and Entrepreneurship, Vol. 12 No. 1, pp.39-52. 
Marshall, B., Cardon, P., Poddar, A. and Fontenot, R. (2013), "Does sample size matter in qualitative research? A review of qualitative interviews in IS research.", Journal of Computer Information Systems, Vol. 54 No. 1, pp.11-22.

Mawson, S. and Kasem, L. (2019), "Exploring the entrepreneurial intentions of Syrian refugees in the UK", International Journal of Entrepreneurial Behaviour and Research, Vol. 25 No. 5, pp.1128-1146.

McDonald, S., Gan, B.C., Fraser, S.S., Oke, A. and Anderson, A.R. (2015), "A review of research methods in entrepreneurship, 1985-2013", International Journal of Entrepreneurial Behavior and Research, Vol. 21 No.03, pp.291-315.

McKeever, E., Jack, S. and Anderson, A. (2015), "Embedded entrepreneurship in the creative reconstruction of place”, Journal of Business Venturing, Vol. 30 No. 1, pp.50-65.

McLeod, J. (2001), Qualitative research in counselling and psychotherapy, Sage Publication ltd., London.

Melis, P., Galletta, M., Gonzalez, C.I.A., Contu, P. and Herrera, M.F.J. (2020), "Ethical perspectives in communication in cancer care: An interpretative phenomenological analysis", Nursing Ethics, Vol. 27 No. 6, pp.1418-1435.

Miner, J.B. (2000), "Testing a psychological typology of entrepreneurship using business founders", Journal of Applied Behavioral Science, Vol. 36 No. 1, pp.43-69.

Mole, K.F. and Mole, M. (2010), "Entrepreneurship as the structuration of individual and opportunity: A response using a critical realist perspective", comment on Sarason, Dean and Dillard, Journal of Business Venturing, Vol. 25 No. 2, pp.230-237. 
Mole, K. and Roper, S. (2012), “The Rational Choice Approach to Entrepreneurship”, in Mole, K., and Ram, M, (Ed.s), Perspectives in Entrepreneurship: A Critical Approach, Palgrave MacMillan, Basingstoke, pp.13-26.

Neergaard, H. and Leitch, C.M. (2015), “Introduction”, in Neergaard, H. and Leitch. C.M. (Ed.s), Handbook of Qualitative Research Techniques and Analysis in Entrepreneurship, Edward Elgar, Cheltenham, pp.01-12.

Neergaard, H. and Ulhoi, J.P. (2007), "Introduction: Methodological variety in entrepreneurship research", in Neergaard, H. and Ulhoi, J.P. (Ed.s), Handbook of Qualitative Research Methods in Entrepreneurship, Edward Elgar, Cheltenham, pp.01-14.

Newth, J. (2018), “Hands-on” vs “arm’s length” entrepreneurship research: Using ethnography to contextualize social innovation", International Journal of Entrepreneurial Behaviour and Research, Vol. 24 No. 3, pp.683-696.

Packard, M.D. (2017), "Where did interpretivism go in the theory of entrepreneurship?" Journal of Business Venturing, Vol. 32 No. 5, pp.536-549.

Paley, J. (2017), Phenomenology as qualitative research: A critical analysis of meaning attribution, Routledge, London.

Palmer, M., Larkin, M., De Visser, R. and Fadden G. (2010), "Developing an interpretative phenomenological approach to focus group data", Qualitative Research in Psychology, Vol. 7 No. 2, pp.99-121.

Pernecky, T. and Jamal, T. (2010), "(Hermeneutic) Phenomenology in tourism studies", Annals of Tourism Research, Vol. 37 No. 4, pp.1055-1075. 
Pietkiewicz, I. and Smith, J.A. (2012), "A practical guide to using interpretative phenomenological analysis in qualitative research psychology", Psychological Journal, Vol. 18 No. 2, pp.361-369.

Pittaway, L. (2000), "The Social Construction of Entrepreneurial Behaviour" [PhD dissertation], Newcastle University, Newcastle (UK).

Raco, J.R. and Tanod, R.H.M. (2014), "The phenomenological method in entrepreneurship, in International Journal of Entrepreneurship and Small Business, Vol. 22 No. 3, pp.276-285.

Rajasinghe, D.R. (2018), "Leadership development through executive coaching: an interpretative phenomenological analysis", PhD thesis, University of Leeds, Leeds (UK).

Rajasinghe, D.R. (2020), "Interpretative phenomenological analysis (IPA) as a coaching research methodology", Coaching: An International Journal of Theory, Research and Practice, Vol. 13 No. 2, pp.176-190.

Rajasinghe, D.R. and Mansour, H. (2019), "Coaching as an Entrepreneurship Learning and Development Tool", in J.J. Turner and G. Mulholland (Ed.s), Enterprise Education in UK Higher Education: Challenges for Theory and Practice, Routledge, London, pp.51-69.

Reid, K., Flowers, P. and Larkin, M. (2005), "Exploring lived experience", The Psychologist, Vol. 18 No.1, pp.20-23.

Ricoeur, P. (1970), Freud and philosophy: an essay on interpretation, (Trans) Denise Savage, Yale University Press, New Haven.

Roberts, T. (2013), "Understanding the research methodology of interpretative phenomenological analysis", British Journal of Midwifery, Vol. 21 No. 3, pp.215-218. 
Rodham, K., Fox, F. and Doran, N. (2015), "Exploring analytical trustworthiness and the process of reaching consensus in interpretative phenomenological analysis: Lost in transcription", International Journal of Social Research Methods, Vol. 18 No. 1, pp.59-71.

Seymour, R.G. (2006), "Hermeneutic phenomenology and international entrepreneurship research", Journal of International Entrepreneurship, Vol. 4 No. 4, pp.137-155.

Shinebourne, P. (2011), "The Theoretical Underpinnings of Interpretative Phenomenological Analysis", Existential Analysis, Vol. 22 No. 1, pp.16-32.

Smith, B. (2018), "Generalizability in qualitative research: misunderstandings, opportunities and recommendations for the sport and exercise sciences", Qualitative Research in Sport, Exercise and Health, Vol. 10 No. 1, pp.137-149.

Smith, J.A. (2011), "Evaluating the contribution of interpretative phenomenological analysis." Health Psychology Review, Vol. 5 No.1, pp.9-27.

Smith, J.A. (2018), "Participants and researchers searching for meaning: conceptual developments for interpretative phenomenological analysis", Qualitative Research in Psychology, Vol. 16 No. 2, pp.166-181.

Smith, J.A. and Eatough, V. (2007), "Interpretative phenomenological analysis", in Lyons, E. and Coyle, A. (Ed.s), Analysing qualitative data in psychology, SAGE, London, pp.35-50.

Smith, J.A. and Osborn, M. (2008), "Interpretative phenomenological analysis", in Smith, J. A. (Ed), Qualitative Psychology: A practical guide to methods, $2^{\text {nd }}$ ed, Sage Publication Ltd., London, pp.53-80. 
Smith, J. A., Flowers, P. and Larkin, M. (2009), Interpretative phenomenological analysis: theory, methods and research, Sage Publication Ltd., London.

Smith, R. and McElwee, G. (2015), "Developing qualitative research streams relating to illegal rural enterprise reflections on researching qualitatively at the margins of entrepreneurship research", International Journal of Entrepreneurial Behaviour and Research, Vol. 21 No. 3, pp.364-388.

Smith, S.M. and McKeever, E. (2015), "Using contact comparison as a method of analysis in entrepreneurship research", in Neergaard, H. and Leitch, C.M. (Ed.s), Handbook of Qualitative Research Techniques and Analysis in Entrepreneurship, Edward Elgar, Cheltenham, pp. 52-73.

Spiers. J., Smith, J.A. and Drage, M. (2016), "A longitudinal interpretative phenomenological analysis of the process of kidney recipients' resolution of complex ambiguities within relationships with their living donors", Journal of Health Psychology, Vol. 20 No. 11, pp.2600-2611.

Stam, E. (2016), "Theorising entrepreneurship in context”, in Welter, F. and Gartner, W.B. (Ed.s), A Research Agenda for Entrepreneurship and Context, Edward Elgar, Cheltenham, pp.93-108.

Steyaert, C. (1997), “A Qualitative Methodology for Process Studies of Entrepreneurship", International Studies of Management \& Organization, Vol. 27 No. 3, pp.13-33.

Steyaert, C. (2007), “'Entrepreneuring' as a conceptual attractor? A review of process theories in 20 years of entrepreneurship studies", Entrepreneurship and Regional Development, Vol. 19(6), pp.453-477.

Steyaert, C. (2016). "After" context. in Welter, F. and Garner, B.W. (Ed.s.), A Research Agenda for Entrepreneurship and Context, Edward Elgar, Cheltenham, pp.28-40. 
Steyaert, C. and Katz, J. (2004), "Reclaiming the space of entrepreneurship in society: geographical, discursive and social dimensions", Entrepreneurship \& Regional Development, Vol. 16 No. 3, pp.179-196.

Van Burg, E., Cornelissen, J., Stam, W., and Jack, S. (2020), "Advancing Qualitative Entrepreneurship Research: Leveraging Methodological Plurality for Achieving Scholarly Impact", Entrepreneurship Theory and Practice, doi: https://doi.org/10.1177/1042258720943051

Van Manen, M. (1997), Researching lived experience: human science for an action sensitive pedagogy, The Althouse Press, Ontario.

Wagstaff, C. and Williams, B. (2014), "Specific design features of an interpretative phenomenological analysis study", Nursing Research, Vol. 21 No. 3, pp.8-12.

Wagstaff, C., Jeong, H., Nolan, M., Wilson, T., Tweedlie, J., Senu, P.E.H. and Holland F. (2014), "The accordion and the deep owl of spaghetti: eight researchers' experiences of using IPA as a methodology", The Qualitative Report, Vol. 19 No. 47, pp.1-15.

Welter, F. (2011), “Contextualizing Entrepreneurship, Conceptual Challenges and Ways Forward", Entrepreneurship, Theory and Practice, Vol. 34, No. 1, pp.165-184.

Welter, F., Gartner, W.B. and Wright, M. (2016), "The context of contextualizing contexts", in Welter, F. and Gartner, W.B, (Ed.s), A Research Agenda for Entrepreneurship and Context, Edward Elgar, Cheltenham, pp.01-15.

Willig, C. (2014), Interpretation and analysis. in Flick, U, (Ed.), "Sage Handbook of Qualitative Data Analysis", Sage, London, pp.136-149. 
Yardley, L. (2000), "Dilemmas in qualitative health research", Psychology and Health, Vol. 15 No. 2, pp.215-228.

Yardley, L. (2008), "Demonstrating validity in qualitative psychology”, in Smith, J.A. (Ed.), Qualitative psychology: a practical guide to method, $2^{\text {nd }}$ ed, Sage Publication Ltd., London, pp. $235-251$. 